\title{
Intraluminally injected oil induces changes in vascular permeability in the 'sensitized' and 'non-sensitized' uterus of the mouse
}

\author{
S. R. Milligan and Florence M. Mirembe* \\ Department of Physiology, King's College, Strand, London WC2R 2LS, U.K.
}

\begin{abstract}
Summary. After suitable sensitization of ovariectomized mice with progesterone and oestradiol, the intrauterine instillation of oil produces a massive decidual cell reaction. Vascular permeability, as reflected by the extra-vascular accumulation of ${ }^{125}$ I-labelled human serum albumin, increased after oil instillation and was maintained at 2-3 times control values for at least the next 3 days. Although oil instillation did not produce a decidual response in females treated with progesterone alone, an increase in vascular permeability (about 2 times control levels) still occurred. This response peaked $8 \mathrm{~h}$ after oil instillation and was not maintained. These results indicate that the progesteronedominated uterus which has not been sensitized with oestradiol cannot be viewed as completely unresponsive to the stimulus of oil and demonstrate that a marked increase in vascular permeability is not itself sufficient to induce decidualization of progesterone-dominated uterine stromal cells. The uterine extravascular accumulation of ${ }^{125} \mathrm{I}$-labelled albumin was increased both in association with tribromoethanol anaesthesia and after oestradiol treatment of progesterone-primed animals. In pregnant mice, the appearance of Pontamine Sky Blue spots provided an earlier indication of implantation than did determination of total uterine extravascular ${ }^{125} \mathrm{I}$ labelled albumin accumulation.
\end{abstract}

\section{Introduction}

Precise endocrine conditions are required for the initiation and development of the decidual cell reaction (Psychoyos, 1973). In mice, exposure for 3 days to a combination of progesterone and small amounts of oestradiol induces maximal sensitivity to a deciduogenic stimulus. In such 'sensitized' females, blastocysts or small amounts of oil readily induce a decidual-cell reaction (Finn, 1965; Humphrey, 1969). Neither of these stimuli is effective in female mice treated with progesterone alone ('non-sensitized'), although the uteri do respond to more traumatic stimuli (Finn, 1965). It is uncertain how the small amounts of oestradiol induce the condition of maximal sensitivity or what physiological differences exist between the sensitized and non-sensitized states (Finn, 1977). The failure of non-sensitized uteri to respond to physiological (i.e. blastocysts) and non-traumatic (i.e. intraluminal oil) stimuli cannot be due to stromal inadequacy because the uteri are still capable of producing a decidual cell response to traumatic stimuli. Martin (1980) proposed that the difference between the uterine states may lie at the level of the luminal epithelium, with the epithelium of nonsensitized uteri being unable to transmit an adequate signal in response to the potential deciduogenic stimulus. The non-sensitized uterus is not entirely unresponsive to the potential deciduogenic stimulus of oil, however, as Milligan \& Lytton (1983) observed a rapid rise in uterine PGF- $\alpha$ concentrations after oil instillation. The significance of the early changes in prostaglandin

\footnotetext{
* Present address: Department of Obstetrics \& Gynaecology, Mulago Hospital, P.O. Box 7051, Kampala, Uganda.
} 
(PG) concentrations after intrauterine oil instillation is uncertain, but changes in vascular permeability invariably precede the decidual cell reaction and PGs have been strongly implicated as mediators in both decidual and vascular responses (Kennedy, 1984). Therefore, although nonsensitized uteri fail to respond to intraluminal oil with a decidual cell reaction, the possibility remains that the $P G$ response that occurs may induce changes in vascular permeability. The primary aim of the present study was to investigate whether this response does occur, using the extravascular accumulation of ${ }^{125}$ I-labelled albumin as a sensitive indicator of vascular permeability. In addition, the general time course of the vascular permeability response accompanying decidualization is reported, together with observations on the effects of the steroid regimen and type of anesthesia.

\section{Materials and Methods}

Animals. Adult Swiss albino female mice (A. Tuck \& Son Ltd, Battlesbridge, Essex, U.K.) weighing $20-30 \mathrm{~g}$ were fed on a pelleted diet $\left(41 \mathrm{~B}\right.$ Oxoid) and were housed at $21^{\circ} \mathrm{C}$ with lights on from $08: 00$ to $24: 00 \mathrm{~h}$. Females were ovariectomized using tribromoethanol anaesthesia 1-2 weeks before use. Injections of oestradiol-17 $\beta$ and progesterone (Sigma London Chemical Co. Ltd, Poole, Dorset, U.K.) were given subcutaneously in $0.1 \mathrm{ml}$ arachis oil (British Drug Houses Ltd, Poole, Dorset, U.K.). The first day of steroid treatment was designated Day 1.

Ovariectomized females were primed with $100 \mathrm{ng}$ oestradiol-17 $\beta$ on Days 1, 2 and 3. From Day 6 , females were treated daily with (i) a combination of progesterone $(1 \mathrm{mg})$ and oestradiol-17 7 (10 $\mathrm{ng}$ ), to produce maximal sensitivity to a decidual stimulus on Day 8 (Finn \& Martin, 1972), or (ii) progesterone $(1 \mathrm{mg}$ ) alone (producing a state in which the potential deciduogenic stimuli of oil or the blastocyst are ineffective). The steroids were given daily at 10:00 h for 3 days. From Day 9 onwards, females received $1 \mathrm{mg}$ progesterone daily.

Intrauterine injection of oil into one uterine horn and/or manipulation of the control horn were performed at 13:00 h on Day 8. Intraluminal injection of $10 \mu \mathrm{l}$ oil was made through a 25 -gauge needle at the anterior tip of the uterine horn using ether or intraperitoneal tribromoethanol anaesthesia. After instillation, the oil is distributed throughout the injected horn but rarely crosses to the contralateral horn (Martin \& Finn, 1979). Control uterine horns were not injected but were otherwise subjected to the same handling procedure as the injected horns.

Estimation of vascular permeability. A quantitative estimate of the permeability of capillaries to large molecules was obtained from the leakage of radiolabelled albumin from the circulation (Arvidson, 1977). Tissue blood volume was estimated from the content of radiolabelled red cells. Isotopes were obtained from Amersham International Ltd (U.K.).

Using ether or tribromoethanol anaesthesia, the external jugular was exposed. The vein was injected with $1 \mu \mathrm{Ci}^{125} \mathrm{I}$-labelled human serum albumin (HSA) and $4 \mu \mathrm{Ci}{ }^{51} \mathrm{Cr}$-labelled mouse red blood cells in a volume of $0.1 \mathrm{ml}$. The red cells were labelled according to the method of Bitton, Vassent \& Psychoyos (1965) and approximately $40 \mu$ labelled red cells were injected into each mouse. Females anaesthetized with tribromoethanol remained under anaesthesia but those injected under ether were allowed to recover. At 30 min after the injection of isotopes, a blood sample $(\sim 200 \mu \mathrm{l})$ was taken from the suborbital canthal sinus (using ether anaesthesia when appropriate) and the females were killed by cervical dislocation. Part of the blood sample was centrifuged to obtain a $50 \mu \mathrm{l}$ plasma sample. The uterine horns and a small piece of diaphragm (as a control tissue) were removed, and gently washed (in $0.154 \mathrm{M}-\mathrm{NaCl}$ ) and blotted before weighing. Radioactivity in tissue, blood and plasma samples was determined using a Nuclear Enterprises automatic gamma counter, with appropriate correction for cross-over between isotopes. All counts were corrected to counts $/ \mathrm{mg}$ tissue. Tissue blood volumes were determined from the relative content of ${ }^{51} \mathrm{Cr}$ in the blood and tissue samples and on the assumption that tissue and systemic 
haematocrits were identical. Extravascular ${ }^{125} \mathrm{I}$-labelled HSA accumulation $\left({ }^{125} \mathrm{I}\right)$ was determined on the assumption that all ${ }^{125} \mathrm{I}$ was protein bound, using the expression:

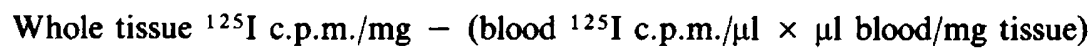

and expressed as:

(extravascular ${ }^{125} \mathrm{I}$ c.p.m./mg tissue)/( ${ }^{125} \mathrm{I}$ c.p.m./ $\mu$ l plasma).

This value $(\mu \mathrm{l} / \mathrm{g})$ is the "apparent plasma equivalent extravascular albumin volume" (Bill, 1964, 1968). No significant change in this volume for the diaphragm was observed at any time in any treatment (regardless of the type of anaesthetic) and the data for this tissue are only presented for Exps 1 and 3.

Experiment 1. Ovariectomized mice were primed with oestradiol and treated daily with progesterone or progesterone plus oestradiol from Day 6. After intrauterine instillation of oil at 13:00 h on Day 8, extravascular ${ }^{125}$ I accumulation was determined at 15:00, 17:00, $21: 00 \mathrm{~h}$ on Day 8, 02:00, 07:00 and 19:00 h on Day 9, and 13:00 h on Days 10 and 11. Tribromoethanol anaesthesia was used both for oil instillation and injection of isotopes.

Experiment 2. Ovariectomized mice were primed with oestradiol and treated daily with progesterone or progesterone plus oestradiol from Day 6. In Exp. 2a, the uteri were not subjected to intraluminal instillation. Extravascular ${ }^{125} \mathrm{I}$ accumulation was determined at 14:00 h on Day 7, $10: 00,13: 00,17: 00$ and $21: 00 \mathrm{~h}$ on Day $8,10: 00 \mathrm{~h}$ on Day 9 and 10:00 h on Day 10. In additional females, one uterine horn was sham instilled at 13:00 h on Day 8 (using ether anaesthesia) and uterine vascular permeability determined at 17:00 and $21: 00 \mathrm{~h}$ on Day 8 and 10:00 h on Day 9. For all animals the tracers were administered using brief ether anaesthesia.

In a separate group of mice (Exp. 2b), one uterine horn was instilled at 13:00 h on Day 8 with 10 $\mu \mathrm{l}$ arachis oil or saline and the control horn was sham injected. Uterine vascular permeability was determined at 21:00 h. All tracers were injected using ether anaesthesia.

Experiment 3. Ovariectomized females primed with oestradiol were treated on Days 6 and 7 with progesterone alone or with progesterone plus oestradiol. Uterine vascular permeability was determined at 10:00 $\mathrm{h}$ on Day 8, using brief ether anaesthesia to inject the tracers. Additional females from both groups were given further steroid treatment (half treated with progesterone alone and half with progesterone plus oestradiol) at 10:00 h. Uterine vascular permeability was determined at 13:00 h using tribromoethanol or brief ether anaesthesia to inject the tracers (see Table 2, Exp. 3a).

The effect of anaesthesia was investigated in an additional group of 30 mice treated with progesterone plus oestradiol (Exp. 3b). In 9 of these, an indwelling cannula was inserted on Day 2, 3 or 4 into one external jugular and exteriorized at the back of the neck. The cannulae were flushed daily with heparinized saline. Uterine vascular permeability was determined at 13:00 h on Day 8 . The tracers were administered using tribromoethanol or brief ether anaesthesia, or without anaesthesia via the indwelling cannula.

Experiment 4. Mature hemi-ovariectomized mice were mated with an intact male (Day $1=$ day of finding copulatory plug). Uterine extravascular albumin volume was determined at 12:00, 16:00, 20:00 and 24:00 h on Day 4. All tracers were administered using light ether anaesthesia. The tracer solution also contained 1\% Pontamine Sky Blue (to demonstrate implantation sites).

Analysis of results. Results were analysed using Student's paired and unpaired $t$ tests, or analysis of variance followed by Duncan's New Multiple Range test (Li, 1957), as appropriate.

\section{Results}

\section{Experiment 1: instillation of oil into sensitized and non-sensitized uteri}

As reflected in the changes in uterine weights, oil instillation produced large decidual cell responses in sensitized uteri (Text-fig. 1a). Only a few small responses, restricted to the site of 


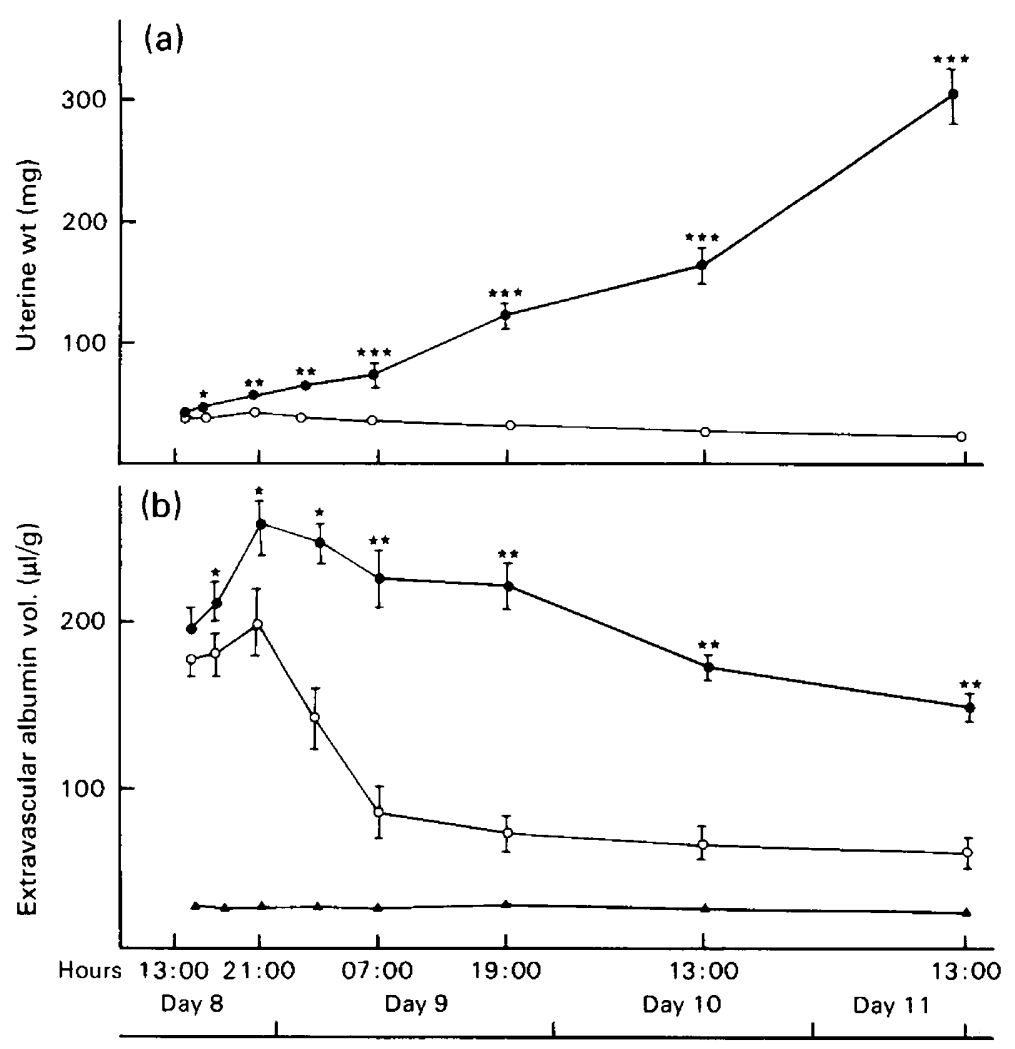

Text-fig. 1. Responses of the oestradiol-sensitized mouse uterus to oil instillation. Females were primed with $100 \mathrm{ng}$ oestradiol- $17 \beta$ on Days $1-3$ and treated with progesterone $(1 \mathrm{mg})$ plus oestradiol (10 ng) on Days 6-8 and with progesterone alone from Day 9. Oil was injected into one uterine horn at 13:00 h on Day 8. (a) Changes in uterine weight in instilled (O) and control (O) uterine horn. (b) Extravascular albumin volume in the instilled (O) and control (O) uterine horns and diaphragm $(\boldsymbol{\Delta})$. Values are means \pm s.e.m. (s.e.m. contained within the symbol when not shown), 7-9 observations at each point. ${ }^{*} P<0.05,{ }^{* *} P<0.01,{ }^{* * *} P<0.001$, compared with controls.

instillation, occurred in non-sensitized uteri (Text-fig. 2a). In the sensitized and non-sensitized animals, the instillation of oil into one uterine horn induced a significant increase in the extravascular accumulation of ${ }^{125} \mathrm{I}$-labelled HSA compared to the control horn (Text-figs $1 \mathrm{~b} \& 2 \mathrm{~b}$ ). In the oil-instilled horns of oestradiol-sensitized mice, the extravascular albumin volume increased slightly after oil injection and remained high for the rest of the observation period. The distinction between the instilled and control horns became evident largely through the decline in uterine extravascular albumin volume in the latter. In non-sensitized uteri, although a small, transient rise in the extravascular albumin volume of control horns occurred, a much greater increase occurred in the oil-instilled horns. It rose rapidly to peak at $21: 00 \mathrm{~h}$ on Day 8 but then fell sharply. In the control horns of oestradiol-sensitized mice, the extravascular albumin volume was significantly higher than in non-sensitized uteri at 15:00, 17:00 and 21:00 h on Day $8(P<0.01, P<0.02$ and $P<$ 0.02 , respectively). None of the changes in extravascular albumin volume in sensitized or nonsensitized uteri was reflected in any significant change in the extravascular albumin volume of the diaphragm (Text-figs $1 \mathrm{~b} \& 2 \mathrm{~b}$ ). 


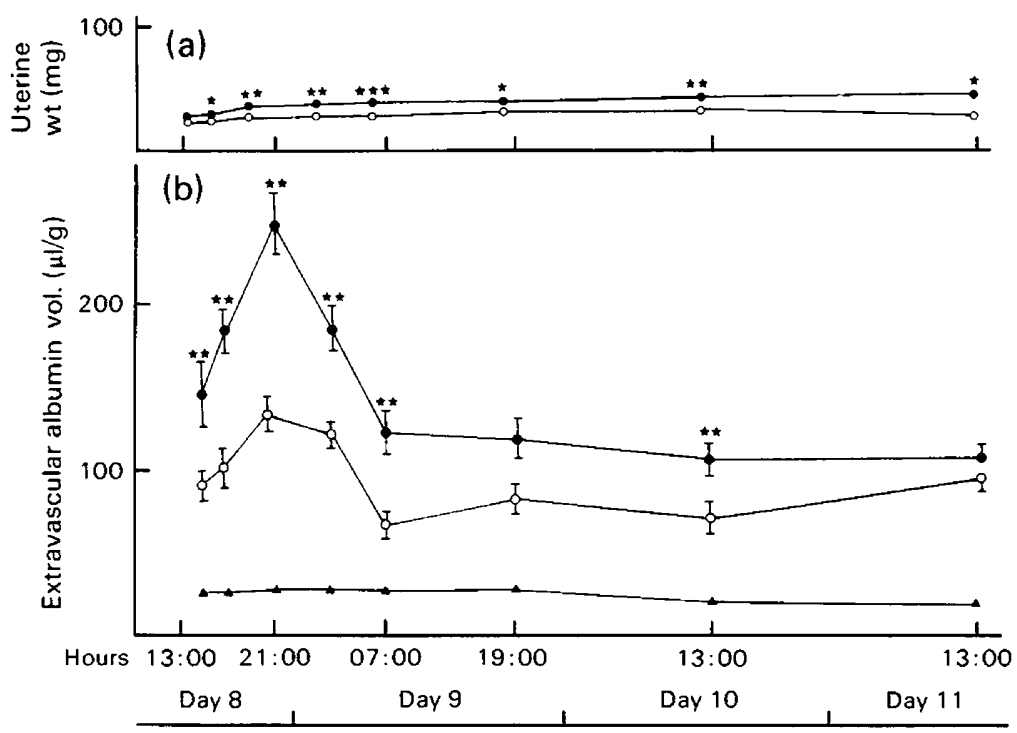

Text-fig. 2. Responses of the non-sensitized mouse uterus to oil instillation. Females were primed with $100 \mathrm{ng}$ oestradiol-17 7 on Days $1-3$ and treated with progesterone $(1 \mathrm{mg})$ alone from Day 6. Oil was injected into one uterine horn at 13:00 h on Day 8. (a) Changes in uterine weight in instilled $(O)$ and control $(O)$ uterine horn. (b) Extravascular albumin volume in the instilled $(O)$ and control $(O)$ uterine horns and diaphragm $(\Delta)$. Values are means \pm s.e.m. (s.e.m. contained within the symbol when not shown), 7-9 observations at each point. ${ }^{*} P<0.05,{ }^{* *} P$ $<0.01,{ }^{* * *} P<0.001$, compared with controls.

Experiment 2: the effect of the steroid regimen and intrauterine oil, saline or sham instillation on vascular permeability

There were no dramatic changes between Days 7 and 9 in the uterine extravascular albumin volume in the females that had been treated with progesterone alone and not subjected to any manipulation of either uterine horn (Table 1). There was no significant effect of anaesthesia and sham instillation at 13:00 h on the uterine extravascular albumin volume of the contralateral control (unhandled) horns at any of the later times, but sham instillation produced a significantly higher value in that horn at 17:00 and $21: 00 \mathrm{~h}$ (i.e. 4 and $8 \mathrm{~h}$ after treatment). Although saline instillation produced a greater increase in uterine extravascular albumin volume at $21: 00 \mathrm{~h}$ (i.e. $8 \mathrm{~h}$ after injection) than did sham injection alone, the response to oil instillation was considerably larger (oil us saline: $t=3.7, n=10, P<0.01$ ).

Uterine extravascular albumin volume in control females (not subject to any instillation or sham-instillation procedure) treated with progesterone plus oestradiol was significantly higher at 14:00 h on Day 7 and 10:00,13:00 and 17:00 h on Day 8 than in females treated with progesterone alone. Particularly high values in the progesterone plus oestradiol-treated females were seen at 14:00 h on Day 7 and 13:00 h on Day 8 (i.e. within a few hours of the daily injection of steroids). Anaesthesia and sham instillation at 13:00 h on Day 8 had no significant effect on uterine extravascular albumin volume in the contralateral control (unhandled) horns, but sham instillation resulted in significantly higher values in that horn at 17:00 h (i.e. $4 \mathrm{~h}$ later). No significant additional elevation in uterine extravascular albumin volume occurred at $21: 00 \mathrm{~h}$ after saline instillation, but the effect of intrauterine oil instillation was significantly greater than that of either of these treatments (oil versus saline: $t=2 \cdot 4, n=8, P<0 \cdot 05$ ). 
Table 1. Uterine extravascular albumin volume $(\mu \mathrm{l} / \mathrm{g})$ after oil, saline or sham instillation (ether anaesthesia, Exp. 2) at 13:00 h on Day 8 in mice primed with $100 \mathrm{ng}$ oestradiol on Days 1, 2 and 3 and treated on Days 6, 7 and 8 with progesterone $(1 \mathrm{mg})$ or progesterone $(1 \mathrm{mg})$ plus oestradiol $(10 \mathrm{ng})$; mice received progesterone only $(1 \mathrm{mg} /$ day) on Days 9 and 10

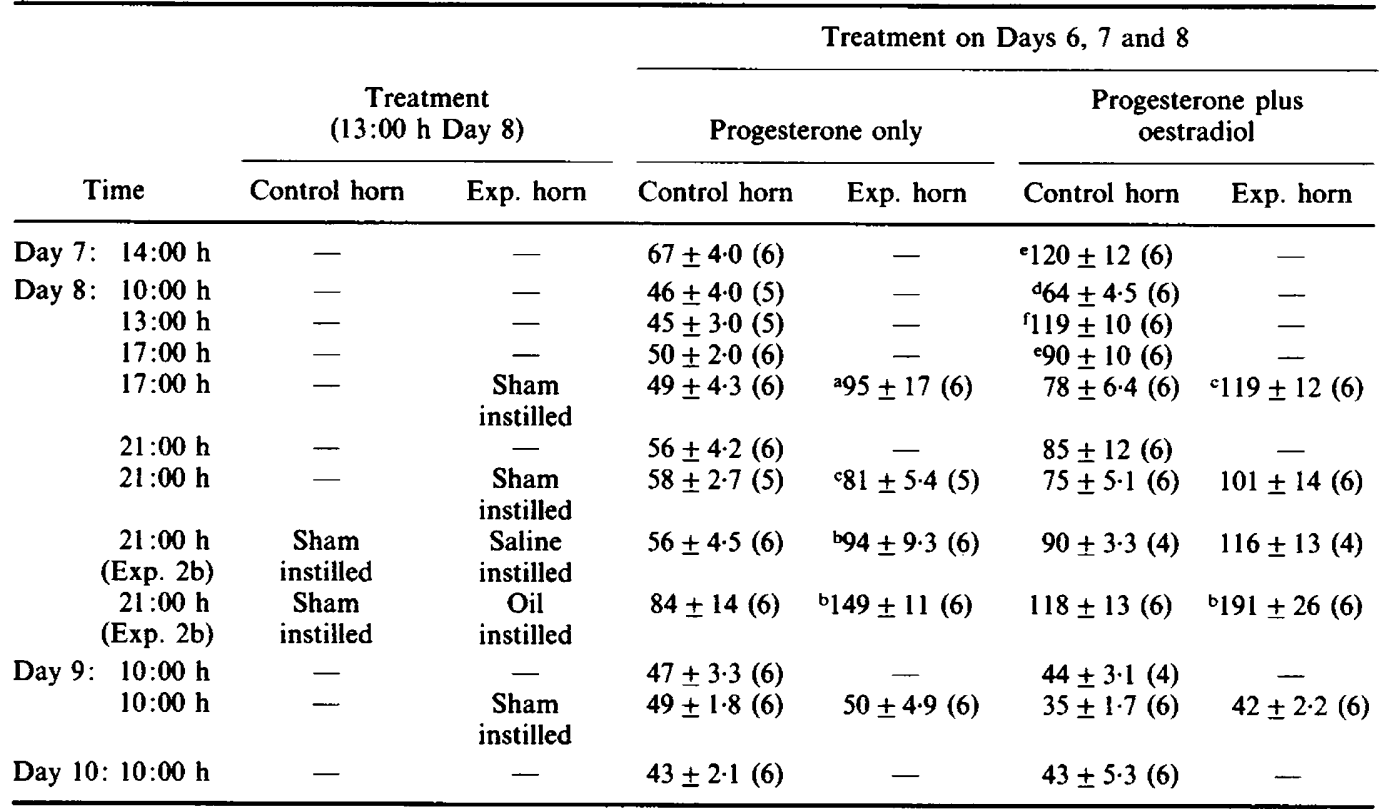

Values are mean \pm s.e.m. for the number of observations in parentheses.

Values significantly different from those of corresponding control horn: ${ }^{a} P<0.05,{ }^{b} P<0.02,{ }^{c} P<0.01$.

Values significantly different from those of corresponding progesterone-only treated animals: ${ }^{\mathrm{d}} P<0.02$, e $P<$ $0.01,{ }^{\mathrm{f}} P<0.001$.

Experiment 3: effects of oestradiol on uterine vascular permeability in progesterone-treated mice and effect of the use of ether or tribromoethanol anaesthesia for tracer injection

Uterine vascular permeability at 10:00 $\mathrm{h}$ on Day 8 was higher in females treated with progesterone plus oestradiol than in females treated with progesterone alone, although this was not statistically significant (Table 2, Treatments 1 and 5). Combining these results with those from Exp. 2, however, showed that at 10:00 h animals previously treated with progesterone plus oestradiol had significantly higher values of uterine extravascular albumin volume $(65.0 \pm 3.6(n=$ 13) compared with $45.2 \pm 1.7(n=12) \mu \mathrm{l} / \mathrm{g}, t=4 \cdot 7, P<0.001)$.

The treatment of either group of females with progesterone plus oestradiol at 10:00 h (Treatments 4 and 6), but not progesterone alone (Treatments 2 and 8) significantly increased the uterine extravascular albumin volume at 13:00 h. The uterine values at 13:00 h were higher when tribromoethanol anaesthesia rather than ether was used to administer the tracers (Treatments 3 and 7), although this effect was only statistically significant for the mice treated with progesterone plus oestradiol. This effect of tribromoethanol in increasing uterine extravascular albumin volume was also apparent in Exp. 3b. There was no significant difference between uterine values determined using the indwelling cannulae (Treatment 9) or brief ether anaesthesia (Treatment 10) to administer the tracers. However, extravascular albumin volumes determined using tribromoethanol anaesthesia (Treatment 11) were significantly higher. There were no significant effects of oestradiol or anaesthetic on the extravascular albumin volume of the diaphragm. 
Table 2. The effect of oestradiol on extravascular albumin volume in progesterone-treated mice and the effect of anaesthesia for tracer injection: females were primed with $100 \mathrm{ng}$ oestradiol-17 $\beta$ on Days 1,2 and 3 and variously treated with $1 \mathrm{mg}$ progesterone $(P)$ or $1 \mathrm{mg}$ progesterone plus $10 \mathrm{ng}$ oestradiol-17 $(\mathrm{P}+\mathrm{e})$ on Days 6-8

\begin{tabular}{|c|c|c|c|c|c|c|}
\hline \multirow[b]{2}{*}{ Treatment } & \multicolumn{2}{|c|}{ Steroid treatment } & \multirow[b]{2}{*}{ Anaesthetic } & \multirow[b]{2}{*}{ Time (Day 8) } & \multicolumn{2}{|c|}{ volume $(\mu \mathrm{l} / \mathrm{g})$} \\
\hline & Day 6 and 7 & Day 8 & & & Diaphragm & Uterus \\
\hline \multicolumn{7}{|l|}{ Exp. $3 a$} \\
\hline 1 & $\mathbf{P}$ & - & Ether & $10: 00 \mathrm{~h}$ & $26 \cdot 0 \pm 1 \cdot 1$ & $44 \pm 1.8(7)$ \\
\hline 2 & $\mathbf{P}$ & $\mathbf{P}$ & Ether & $13: 00 \mathrm{~h}$ & $25.2 \pm 1.6$ & $54 \pm 4 \cdot 2(7)$ \\
\hline 3 & $\mathbf{P}$ & $\mathbf{P}$ & Tribromoethanol & $13: 00 \mathrm{~h}$ & $25 \cdot 4 \pm 1 \cdot 3$ & $75 \pm 6 \cdot 1(6)$ \\
\hline 4 & $\mathbf{P}$ & $P+e$ & Ether & $13: 00 \mathrm{~h}$ & $27 \cdot 8 \pm 2 \cdot 3$ & $85 \pm 1 \cdot 2(6)$ \\
\hline 5 & $P+e$ & - & Ether & $10: 00 \mathrm{~h}$ & $26.2 \pm 1.6$ & $66 \pm 5.8(7)$ \\
\hline 6 & $P+e$ & $P+e$ & Ether & $13: 00 \mathrm{~h}$ & $26.4 \pm 2 \cdot 1$ & $99 \pm 6.4(6)$ \\
\hline 7 & $P+e$ & $\mathrm{P}+\mathrm{e}$ & Tribromoethanol & $13: 00 \mathrm{~h}$ & $24.4 \pm 1.8$ & $140 \pm 22(6)$ \\
\hline 8 & $P+e$ & $\mathbf{P}$ & Ether & $13: 00 \mathrm{~h}$ & $27 \cdot 3 \pm 2 \cdot 5$ & $62 \pm 4 \cdot 2(6)$ \\
\hline \multicolumn{7}{|l|}{ Exp. $3 b$} \\
\hline 9 & $P+e$ & $\mathbf{P}+\mathbf{e}$ & None (cannulated) & $13: 00 \mathrm{~h}$ & $28 \cdot 6 \pm 2 \cdot 1$ & $74 \pm 6 \cdot 3(9)$ \\
\hline 10 & $\mathbf{P}+\mathrm{e}$ & $\mathbf{P}+\mathrm{e}$ & Ether & $13: 00 \mathrm{~h}$ & $28 \cdot 4 \pm 1 \cdot 3$ & $75 \pm 4.9(11)$ \\
\hline 11 & $P+e$ & $P+e$ & Tribromoethanol & $13: 00 \mathrm{~h}$ & $24 \cdot 7 \pm 2 \cdot 3$ & $121 \pm 5 \cdot 3(10)$ \\
\hline
\end{tabular}

Values are mean \pm s.e.m. for the number of observations in parentheses.

Statistical differences between uterine extravascular albumin volumes:

Exp. 3a: Treatment 1 us $4, P<0.01$.

Treatment 2 vs $4, P<0.05$.

Treatment 5 vs $6, P<0.05$.

Treatment 6 vs $7, P<0.01$.

Treatment 6 vs $8, P<0.05$.

Exp. 3b: Treatment 11 os 9 and $10, P<0.01$.

Table 3. Uterine extravascular albumin volume (mean \pm s.e.m.) in relation to the appearance of implantation sites in hemiovariectomized mice (Exp. 4)

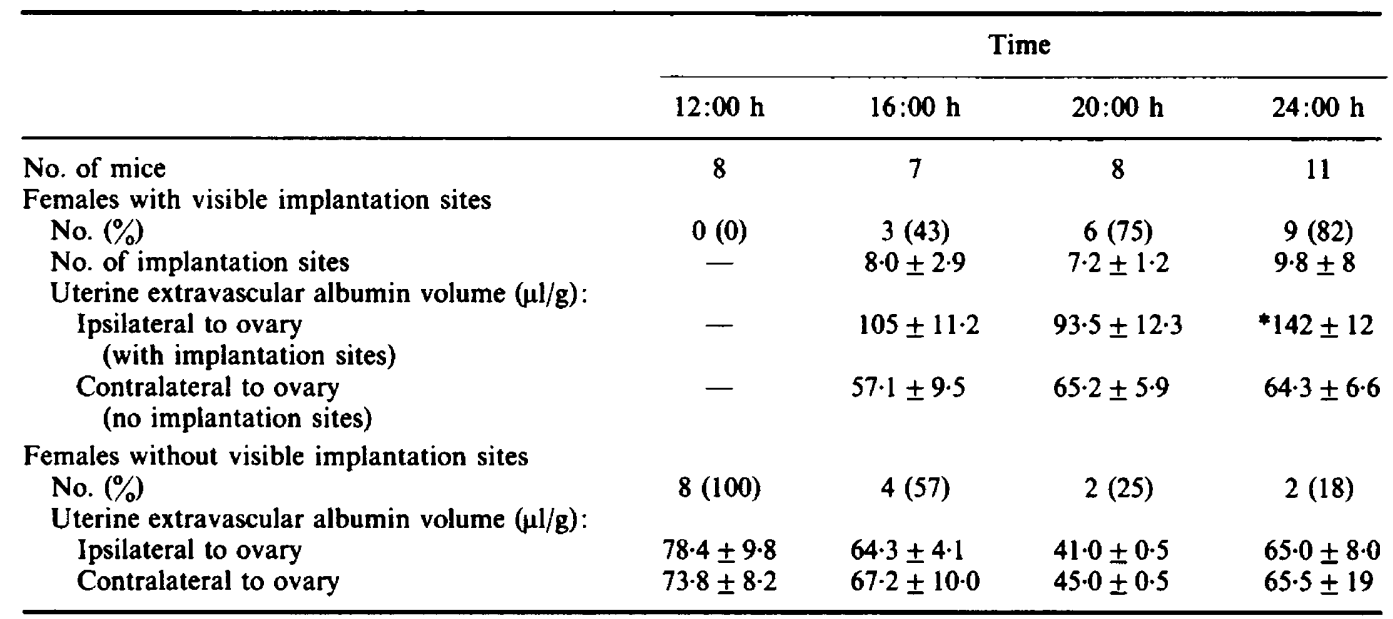

* Value significantly different from that of contralateral horn: $P<0.001$. 


\section{Experiment 4 : uterine vascular permeability in early pregnancy}

Implantation sites (blue spots) were first seen at 16:00 h on Day 4 and were apparent in over $80 \%$ of the females by $24: 00 \mathrm{~h}$ (Table 3 ). All implantations were ipsilateral to the remaining ovary. The appearance of visible implantation sites was associated with an increase in uterine extravascular albumin volume although the difference between the uterine horns with implantation sites and those without only became significant at $24: 00 \mathrm{~h}$. In the absence of visible implantation sites, there was no detectable increase in extravascular albumin volume in the uterine horn ipsilateral to the remaining ovary.

\section{Discussion}

Small amounts of oestradiol in addition to progesterone are required for the full development of the decidual response in the mouse after intraluminal oil instillation (Finn, 1965). Although the decidual reaction does not develop in the absence of oestradiol sensitization, the results of this study clearly demonstrate that the intraluminal injection of oil still induces a marked increase in the vascular permeability to ${ }^{125} \mathrm{I}$-labelled albumin lasting several hours. Milligan \& Lytton (1983) also observed increases in uterine PG levels after oil instillation in the oestradiol-sensitized and nonsensitized states. Together, these results clearly indicate that the non-sensitized mouse uterus cannot be regarded as simply unresponsive to the oil stimulus. Changes in PG levels and increases in vascular permeability are usually considered as integral components of the decidual cell reaction and the reason for the failure of the development of the full response in the non-sensitized mice is unknown. The stromal cells of progesterone only-treated mice are capable of undergoing decidualization in response to more traumatic stimuli (Finn, 1965) and previously it has been proposed that, in the absence of small amounts of oestradiol, the uterine epithelium may be simply unresponsive to the oil stimulus (Martin, 1980). The changes observed in uterine PGs (Milligan \& Lytton, 1983) and vascular permeability suggest that this is not the case. One possibility is that the signals mediating the vascular and decidual responses may be different from each other, and uteri which have not been sensitized by oestradiol may be unable to produce the appropriate signal for decidualization. Alternatively, if the epithelium can generate the appropriate signals, the failure of decidualization may reflect an insensitivity of the stromal cells to respond. In this connection, Kennedy, Martel \& Psychoyos (1983) reported that oestradiol sensitization in rats does increase uterine endometrial binding sites for PGs. For either of these possibilities, more traumatic stimuli may induce a decidual cell response by changing the nature, strength or source of the signals involved.

Whether the early increases in PG levels that occur in the sensitized and non-sensitized uteri after oil instillation (Milligan \& Lytton, 1983) are responsible for the vascular permeability changes is uncertain. Although the time courses of the vascular responses differ in the two states, neither correlates well with the rapid changes in PG levels (Milligan \& Lytton, 1983). However, indomethacin does inhibit the vascular responses to oil instillation in sensitized mice (Rankin, Ledford, Jonsson \& Baggett, 1979; Buxton \& Murdoch, 1982). Various other signals have been implicated in the induction of the vascular and decidual responses in rats and mice, including cAMP and histamine (Brandon, 1980; Kennedy, 1984). The role and interactions of these various potential signals in the sequence of vascular and stromal cell responses that together constitute the decidual cell reaction remain to be elucidated. Increased vascular permeability is normally intimately associated with decidualization (Psychoyos, 1973) and Sorger \& Soderwall (1981) suggested that oedema may provide a signal for growth of the uterine tissues. It is clear from the present study that a marked increase in vascular permeability is not by itself sufficient to induce a decidual cell reaction in non-sensitized uteri. Increased vascular permeability may not be sufficient to induce decidualization even in oestradiol-sensitized uteri: Finn (1965) and Humphrey \& Martin 
(1968) found that a wide range of mast cell, capillary permeability and inflammatory factors were ineffective in inducing a decidual cell reaction in pseudopregnant females. Whether the shorter duration of increased vascular permeability in the non-sensitized uteri is in any way a limiting factor to decidualization is unknown.

The time course and magnitude of the changes in uterine vascular permeability were dependent on the endocrine status, with the highest uterine extravascular albumin volumes in animals treated with progesterone plus oestradiol. The effect of oestradiol in increasing uterine extravascular albumin volume was particularly marked within a few hours of the oestradiol injection (Exps 2 \& 3). This is consistent with the development of stromal oedema observed after oestradiol injection of progesterone-treated rats (Lundkvist, 1979) and mice (Martin, Hallowes, Finn \& West, 1973) and the development of stromal oedema in the preimplantation period (McLaren, 1970; Lobel, Levy \& Shelesnyak, 1967). Martin et al. (1973) also reported a $17 \%$ increase in the proportion of fenestrated uterine capillaries $6 \mathrm{~h}$ after oestradiol injection into progesterone-treated mice. The additional effect of tribromoethanol anaesthesia in increasing uterine extravascular albumin volume (Exp. 3) has not previously been reported and may be an important consideration in dynamic or ultrastructural studies of uterine vascular permeability.

The instillation of oil induces a decidual cell reaction similar to that caused by a blastocyst and the endocrine requirements for the development of responses to either of these stimuli are identical (Finn, 1965). In view of this, the intraluminal instillation of oil has been used extensively as a nontraumatic decidualizing stimulus in the belief that it mimics closely the stimulus and effects of the blastocyst (Finn, 1977). The degree to which the oil stimulus does resemble the blastocyst, however, may need to be questioned. Oil instillation induces a marked vascular response in non-sensitized uteri, but there is no suggestion in the literature that such vascular changes occur in non-sensitized uteri in response to blastocysts (Enders \& Given, 1977). It may be that, as in the rat (Lundkvist \& Nilsson, 1982), oil instillation may represent a rather more traumatic stimulus than has previously been thought.

Increased extravascular accumulation of protein-bound ${ }^{125} \mathrm{I}$ is a sensitive quantitative indicator of the increased uterine vascular permeability preceding the artificially induced decidual reaction (Bitton et al., 1965; Milligan \& Mirembe, 1984). The results of Exp. 4, however, suggest that the extracellular accumulation of visible markers is a more useful indicator of the early uterine responses accompanying natural implantation in the mouse. Although the extracellular accumulation of visible dyes may be less readily quantifiable than is ${ }^{125}$ I-labelled albumin accumulation, it has the advantage of discrete localization. In contrast, although increased accumulation of extravascular ${ }^{125}$ I-labelled albumin occurs at implantation sites, the magnitude of the response is effectively diluted by the large amount of inter-implantation uterine tissue.

We thank Simon Devine for technical assistance, The Wellcome Trust for funding this research, and the British Council for the support of F.M.M.

\section{References}

Arvidson, N.G. (1977) Early oestrogen-induced changes in uterine albumin exchange in mice. Acta physiol. scand. 100, 325-331.

Bill, A. (1964) The albumin exchange in the rabbit eye. Acta physiol. scand. 60, 18-29.

Bill, A. (1968) Capillary permeability to and extravascular dynamics of myoglobin, albumin and gammaglobulin in the uvea. Acta physiol. scand. 73, 204-219.

Bitton, V., Vassent, G. \& Psychoyos, A. (1965) Response vasculaire de l'uterus au traumatisme, au cours de la pseudogestation chez la ratte. C. r. hebd. Séanc. Acad. Sci. Paris D 261, 3474-3477.

Brandon, J.M. (1980) Some recent work on the role of histamine in ovum implantation. In Progress in Reproductive Biology, Vol. 7, pp. 244-252. Eds F. Leroy, C. A. Finn, A. Psychoyos \& P. O. Hubinont. Karger, Basel.

Buxton, L.E. \& Murdoch, R.N. (1982) Lectins, calcium ionophore A23187 and peanut oil as deciduogenic agents in the uterus of pseudopregnant mice: effects 
of tranylcypromine, indomethacin, iproniazid and propanolol. Aust. J. biol. Sci. 35, 63-72.

Enders, A.C. \& Given, R.L. (1977) The endometrium of delayed and early implantation. In Biology of the Uterus, pp. 203-243. Ed. R. M. Wynn. Plenum Press, New York.

Finn, C.A. (1965) Oestrogen and the decidual cell reaction of implantation in mice. J. Endocr. 32, 223229.

Finn, C.A. (1977) The implantation reaction. In Biology of the Uterus, pp. 245-308. Ed. R. M. Wynn. Plenum Press, New York.

Finn, C.A. \& Martin, L. (1972) Endocrine control of the timing of endometrial sensitivity to a decidual stimulus. Biol. Reprod. 7, 82-86.

Humphrey, K.W. (1969) Induction of implantation of blastocysts transferred to ovariectomized mice. $J$. Endocr. 44, 299-305.

Humphrey, K.W. \& Martin, L. (1968) Attempted induction of deciduomata in mice with mast-cell, capillary permeability and tissue inflammatory factors. J. Endocr. 42, 129-141.

Kennedy, T.G. (1984) Embryonic signals and the initiation of blastocyst implantation. Aust. J. biol. Sci. 36, 531-543.

Kennedy, T.G., Martel, D. \& Psychoyos, A. (1983) Endometrial prostaglandin $E_{2}$ binding : characterization in rats sensitized for the decidual cell reaction and changes during pseudopregnancy. Biol. Reprod. 29, 556-564.

Li, J.C.R. (1957) Introduction to Statistical Inference. Edward Brothers, Ann Arbor.

Lobel, B.L., Levy, E. \& Shelesnyak, M.C. (1967) Studies on the mechanism of nidation. XXXIV. Dynamics of cellular interactions during progestation and implantation in the rat. Acta endocr., Copenh., Suppl. 123, 1109.

Lundkvist, O. (1979) Morphometric estimation of stromal oedema during delayed implantation in the rat. Cell Tiss. Res. 199, 339-348.

Lundkvist, O. \& Nilsson, B.O. (1982) Endometrial ultrastructure in the early uterine response to blastocysts and artificial deciduogenic stimuli in rats. Cell Tiss. Res. 225, 355-364.
Martin, L. (1980) What roles are fulfilled by uterine epithelial components in implantation? In Progress in Reproductive Biology, Vol. 7, pp. 54-69. Eds F. Leroy, C. A. Finn, A. Psychoyos \& P. O. Hubinont. Karger, Basle.

Martin, L. \& Finn, C.A. (1979) Varying effects of an IUD on decidualization in mice. J. Reprod. Fert. 55, 125133.

Martin, L., Hallowes, R.C., Finn, C.A. \& West, D.G. (1973) Involvement of the uterine blood vessels in the refractory state of the uterine stroma which follows oestrogen stimulation in progesterone-treated mice. J. Endocr. 56, 309-314.

McLaren, A. (1970) Early embryo-endometrial relationships. In Ovo-implantation, pp. 18-37. Eds P. O. Hubinont, F. Leroy, C. Robyn \& P. Leleux. Karger, Basle.

Milligan, S.R. \& Lytton, F.D.C. (1983) Changes in prostaglandin levels in the sensitized and nonsensitized uterus of the mouse after the intrauterine instillation of oil or saline. J. Reprod. Fert. 67, 373377.

Milligan, S.R. \& Mirembe, F.M. (1984) Time course of the changes in uterine vascular permeability associated with the development of the decidual cell reaction in ovariectomized, steroid-treated rats. J. Reprod. Fert. 70, 1-6.

Psychoyos, A. (1973) Endocrine control of egg implantation. In Handbook of Physiology, Section 7, Vol. II, Part 2, pp. 187-215. Eds R. O. Greep, E. G. Astwood \& S. R. Geiger. Am. Physiol. Soc., Washington, D.C.

Rankin, J.C., Ledford, B.E., Jonsson, H.T. \& Baggett, B. (1979) Prostaglandins, indomethacin and the decidual cell reaction in the mouse uterus. Biol. Reprod. 20, 399-404.

Sorger, T. \& Soderwall, A. (1981) The aging uterus and the role of edema in endometrial function. Biol. Reprod. 24, 1135-1144. 